\title{
THE EFFECT OF TAX AVOIDANCE, EARNINGS MANAGEMENT AND POLITICAL CONNECTION ON CORPORATE SOCIAL RESPONSIBILITY DISCLOSURE : INDONESIAN MANUFACTURING COMPANIES EVIDENCE
}

\author{
Mala Ayu Anggita1, Trisandi Eka Putri ${ }^{2}$, Asep Kurniawan ${ }^{3}$ \\ STIE Sutaatmadja, Subang, Indonesia ${ }^{2}$ \\ malaayuanggita@gmail.com
}

\begin{tabular}{|c|c|}
\hline INFO ARTIKEL & ABSTRAK/ABSTRACT \\
\hline $\begin{array}{l}\text { Histori Artikel : } \\
\text { Tgl. Masuk : } 28 \text { September } 2019 \\
\text { Tgl. Diterima : } 30 \text { September } 2019 \\
\text { Tersedia Online : } 30 \text { September } 2019 \\
\end{array}$ & $\begin{array}{l}\text { The purpose of this study to determine the effect of tax } \\
\text { avoidance, earnings management, and political connection } \\
\text { on the corporate social responsibility disclosure (case } \\
\text { studies on manufacturing companies listed on the idx for the }\end{array}$ \\
\hline $\begin{array}{l}\text { Keywords: } \\
\text { Tax Avoidance, Earnings } \\
\text { Management, Political } \\
\text { Connection, Corporate Social } \\
\text { Responsibility Disclosure }\end{array}$ & $\begin{array}{l}\text { period 2016-2017). This study uses a quantitative } \\
\text { approach. The population in this study were all } \\
\text { manufacturing companies listed on the IDX for the period } \\
2016-2017 \text {. The analytical method used in this study is } \\
\text { descriptive analysis, classic assumption test and multiple } \\
\text { linear regression analysis. The results showed that partially, } \\
\text { tax avoidance and earnings management had no effect on } \\
\text { corporate social responsibility disclosure, and political } \\
\text { connections had a positive effect on corporate social } \\
\text { responsibility disclosure. While simultaneously, tax } \\
\text { avoidance, earnings management and political connection } \\
\text { have an effect on jointly on corporate social responsibility } \\
\text { disclosure }\end{array}$ \\
\hline
\end{tabular}

\section{PENDAHULUAN}

Kehadiran perusahaan
sebagai bagian dari masyarakat
diharapkan dapat memberikan
manfaat bagi masyarakat sekitar.
Namun, kenyataannya semakin
berkembangnya suatu perusahaan
akan berdampak pada kesenjangan
sosial dan kerusakan lingkungan yang
semakin tinggi, hal tersebut
diakibatkan oleh aktivitas operasi
perusahaan terhadap sumber daya
yang tidak terkendali dengan tujuan
untuk meningkatkan laba perusahaan.
Dampak dari aktivitas operasi
perusahaan juga dirasakan oleh
masyarakat dan lingkungan sekitar

perusahaan. Oleh karena itu, perusahaan saat ini diharapkan tidak hanya memperhatikan aspek keuangan perusahaan semata (single bottom line) melainkan meliputi aspek keuangan, aspek sosial dan aspek lingkungan (triple bottom line). Tidak dapat dipungkiri bahwa suatu respon positif dari masyarakat dibutuhkan oleh perusahaan demi mencapai suksesnya suatu entitas melalui apa yang dilakukan oleh perusahaan kepada para stakeholders, termasuk masyarakat dan lingkungan sekitar. Menurut Suryadewi dan Rasmini (2018) : "Tanggungjawab suatu perusahaan terhadap lingkungan dan 
masyarakat, baik yang secara langsung terkait maupun tidak dengan perusahaan dikenal dengan istilah Corporate Social Responsibility (CSR)."

Di Indonesia, pada awalnya Corporate Social Responsibility (CSR) merupakan kegiatan yang berdasarkan kerelaan/sukarela dan bukan paksaan. Akibatnya, masih banyak perusahaan yang berorientasi pada laba tanpa memperdulikan tanggungjawab mereka terhadap kondisi sosial dan lingkungan. Namun sejak tahun 2007 lalu, pelaksanaan CSR telah diatur oleh pemerintah dalam Undang-Undang RI No. 40 tahun 2007 pasal 74 tentang "Tanggung Jawab Sosial dan Lingkungan". Undang-undang tersebut mengamanatkan bahwa "Perseroan yang menjalankan kegiatan usahanya di bidang dan/atau berkaitan dengan sumber daya alam wajib melaksanakan Tanggung Jawab Sosial dan Lingkungan" (Hutasoit, 2018).

\section{Sedangkan}

untuk pengungkapan laporan tanggung jawab sosial perusahaannya itu sendiri, di Indonesia telah diatur oleh Otoritas Jasa Keuangan dalam Surat Eradan Otoritas Jasa Keuangan Nomor 30/SEOJK.04/2016 tentang "Bentuk Dan Isi Laporan Tahunan Emiten Dan Perusahaan Publik". Dalam surat edaran tersebut disebutkan bahwa dalam laporan tahunan yang diterbitkan oleh setiap emiten dan perusahaan publik wajib berisi salah satunya ialah pengungkapan laporan tanggung jawab sosial perusahaan yang mana didalamnya berisi beberapa aspek terkait, seperti; lingkungan, sosial, ketenagakerjaan, dan produk.
Sejak diberlakukannya beberapa aturan tersebut, tidak semua perusahaan melaksanakan kewajibannya sesuai aturan yang telah ditetapkan. Menurut Verani (2012) dalam Tiarawati (2015) : "Kewajiban penerapan konsep CSR dianggap bertentangan dengan prinsip dasar CSR dalam sudut pandang PSAK No 1 yaitu kesukarelaan." Akibatnya perusahaan melaksanakan CSR hanya sebagai formalitas. Perbedaan peraturan mengenai CSR menyebabkan pelaksanaan CSR di Indonesia belum efektif dibandingkan dengan negara lainnya. Ketidakefektifan pelaksanaan CSR di Indonesia tercermin dari beberapa kasus yang muncul, seperti kasus lumpur lapindo yang terjadi di Sidoarjo. Yang mana kasus tersebut merupakan salah satu kasus kerusakan lingkungan sebagai akibat dari kegiatan operasional PT Lapindo Brantas yang kurang memperhatikan masalah lingkungan (Hutasoit, 2018).

Kasus lumpur lapindo sudah berlangsung 12 tahun lamanya, namun belum ada titik terang kapan kasus tersebut akan usai. Selain permasalahan lumpur panas yang terus menyembur sampai sekarang, menurut salah satu warga korban lumpur lapindo pihak perusahaan belum juga menyelesaikan urusan ganti rugi sampai saat ini. Salah satu penyebab tidak kunjung terselesaikannya urusan ganti rugi dikarenakan pihak perusahaan sudah tidak sanggup lagi membayar ganti rugi. Hal tersebut jelas menunjukan betapa pentingnya CSR bagi perusahaan. Meski beban yang dikeluarkan untuk pelaksanaan CSR sangatlah tinggi, namun dampak positif yang akan didapatkan perusahaan apabila melaksanakan CSR sangatlah besar (TRIBUNJATIM.com diakses pada 28 Desember 2018). 
Selain itu, riset terbaru menyatakan perusahaan di Indonesia memiliki kualitas tanggung jawab sosial atau corporate social responsibility (CSR) yang lebih rendah dibandingkan dengan perusahaan asal Thailand. Riset Centre for Governance, Institutions, and Organizations National University of Singapore (NUS) Business School memaparkan rendahnya pemahaman perusahaan di Indonesia terhadap praktik CSR, menyebabkan rendahnya kualitas pengoperasian agenda tersebut. Riset itu melakukan studi terhadap 100 perusahaan di empat negara yakni Indonesia, Malaysia, Singapura dan Thailand. Riset tersebut memaparkan Thailand menjadi negara dengan kualitas implementasi CSR paling tinggi dengan nilai 56,8 dari total 100 , sementara Singapura mendapatkan 48,8. Indonesia dan Malaysia sendiri masing-masing mendapatkan nilai 48,4 dan 47,7 (CNNIndonesia.com diakses pada 28 Desember 2018).

Rendahnya pengungkapan tanggung jawab sosial perusahaan dipengaruhi oleh beberapa faktor diantaranya penghindaran pajak, manajemen laba dan koneksi politik. Faktor pertama yang mempengaruhi CSR ialah penghindaran pajak. Menurut Undang-Undang No 28 tahun 2007 ayat 1 pasal 1 : "Pajak adalah kontribusi wajib kepada negara yang terutang oleh orang pribadi atau badan yang bersifat memaksa berdasarkan Undang-Undang, dengan tidak mendapatkan imbalan secara langsung yang digunakan untuk keperluan negara bagi sebesarbesarnya kemakmuran rakyat." Dari pengertian diatas dapat disimpulkan bahwa beban pajak merupakan salah satu beban yang setiap tahunnya wajib dikeluarkan setiap perusahaan kepada negara.
Pajak yang dibayarkan perusahaan terhitung dari laba bersih perusahaan. Oleh karena itu, bagi suatu perusahaan, pajak dianggap sebagai biaya yang dapat mengurangi keuntungan dari perusahaan sehingga dapat memperkecil laba bersih. Kondisi tersebut mengakibatkan banyak perusahaan berusaha untuk mencari suatu cara agar dapat mengurangi biaya pajak yang harus dibayar.

Menurut Lanis \& Richardson (2012) : "Penghindaran pajak merupakan contoh dari strategi pengurangan pajak yang legal atau diperbolehkan oleh aturan." Biasanya, perusahaan yang diketahui oleh masyarakat melakukan tindakan penghindaran pajak akan mendapatkan penilaian buruk dari masyarakat. Oleh karena itu, pengungkapan CSR dianggap sebagai salah satu media perusahaan untuk menjaga pandangan positif dari masyarakat (Desai dan Dharmapala, 2006). Maka dari itu tindakan penghindaran pajak mempengaruhi perusahaan dalam mengungkapkan CSR. Karena semakin tinggi tindakan penghindaran pajak yang dilakukan perusahaan, maka semakin tinggi pula motivasi perusahaan dalam mengungkapkan CSR, guna menjaga citra baik perusahaan.

Faktor kedua yang mempengaruhi CSR yaitu manajemen laba. Menurut Terzaghi (2012) : "Manajemen laba dapat dilakukan oleh manajemen perusahaan untuk mengelabui para pemangku kepentingan, dengan memanfaatkan aktivitas yang berkaitan dengan sosial." Kegiatan yang berkaitan dengan CSR dapat digunakan oleh manajer perusahaan dalam menghadapi konflik kepentingan dengan para pemangku kepentingan 
yang memiliki kepentingan yang berbeda.

Untuk mengalihkan perhatian stakeholders terkait dengan manajemen laba yang dilaksanakan perusahaan, perusahaan akan menggunakan strategi agar keberadaan perusahaan tetap mendapatkan legitimasi positif dengan cara melaksanakan tanggung jawab sosial atau lebih dikenal dengan istilah Corporate Social Responsibility (CSR). Pengungkapan CSR dinilai mampu untuk memberikan citra yang baik untuk perusahaan sehingga mendapatkan respon yang positif dari berbagai pihak termasuk stakeholders. Maka dari itu manajemen laba mempengaruhi pengungkapan CSR. Karena semakin tinggi tindakan manajemen laba yang dilakukan perusahaan, maka akan semakin tinggi pula keinginan perusahaan dalam menjaga citra baik perusahaan dengan cara mengungkapkan CSR.

Berbeda halnya dengan kedua faktor diatas yang menyatakan bahwa CSR dapat menyembunyikan tindakan perusahaan dalam melakukan penghindaran pajak maupun manajemen laba, faktor ketiga yaitu koneksi politik menggunakan CSR sebagai alat untuk mematahkan anggapan bahwasannya ada ketidakadilan dari segi aturan dan hukum untuk perusahaan milik swasta dibandingkan dengan perusahaan perusahaan milik negara yang memiliki hubungan dekat dengan pemerintah (koneksi politik). Diberlakukannya Undang-Undang terkait dengan kewajiban mengungkapkan CSR yang dikeluarkan pemerintah merupakan salah satu upaya pemerintah mengatasi permasalahan tersebut (Huang dan Zhao, 2016).

$$
\text { Menurut Faccio (2006) : }
$$

"Koneksi politik terjadi jika pemegang saham otoritas atau petinggi perusahaan adalah anggota parlemen, menteri atau kepala negara, terkait dengan pejabat-pejabat negara, dan lembaga kenegaraan." Maka dari itu perusahaan yang berkoneksi secara politik dianggap akan mendapatkan keistimewaan dari segi aturan dan hukum. Karenanya perusahaan yang tidak berkoneksi secara politik harus membangun hubungan yang baik dengan pemerintah secara aktif, guna memperoleh keadilan kebijakan yang sama seperti halnya perusahaan yang berkoneksi secara politik. Dihadapkan dengan keadaan tersebut, perusahaan yang tidak berkoneksi secara politik akan lebih termotivasi untuk mengungkapkan CSR dibandingkan dengan perusahaan yang telah berkoneksi politik guna membangun hubungan baik dengan pemerintah.

Sebelumnya telah banyak peneliti yang melakukan penelitian mengenai Corporate Social Responsibility (CSR) diantaranya: (1) penelitian yang dilakukan oleh Shafai et al (2018) mengemukakan bahwa tax avoidance dan earnings management berpengaruh positif terhadap corporate social responsibility, (2) penelitian yang dilakukan oleh Dharma dan Noviari (2017) menyatakan bahwa corporate social responsibility berpengaruh negatif terhadap tax avoidance. (3) penelitian yang dilakukan oleh Jordaan et al (2018) mengemukakan bahwa corporate social responsibility berpengaruh negatif terhadap earnings management. Mengacu pada hasil penelitian sebelumnya yang belum menunjukan hasil yang mendukumg, maka peneliti tertarik untuk meneliti lebih lanjut dengan menambahkan variabel political connection sebagai variabel baru dalam penelitian ini, dengan studi kasus yang berbeda dari peneliti sebelumnya yang dilakukan oleh Rahman dan Ismail, 2016 yaitu 
pada perusahaan manufaktur yang terdaftar di Bursa Efek Indonesia.

\section{KERANGKA TEORITIS DAN PENGEMBANGAN HIPOTESIS}

\section{Teori Agensi (Agency Theory)}

Agency theory menjelaskan hubungan keagenan yang terjadi antara satu atau lebih orang (principal) dengan orang lain (agent) dalam sebuah kontrak, dimana agent diminta untuk mewakili principal dalam membuat keputusan. Principal adalah pemilik saham yang diwakili oleh dewan komisaris sedangkan agent adalah manajemen pengelola perusahaan yang diwakili oleh dewan direksi (Wulandari, 2018).

\section{Stakeholder Theory}

Stakeholder

theory

menjelaskan bahwa kinerja sebuah organisasi dipengaruhi oleh semua stakeholder organisasi, oleh karena itu merupakan tanggung jawab manajerial untuk memberikan benefit kepada semua stakeholder yang berpengaruh terhadap kinerja organisasi. Teori ini juga menjelaskan bahwa tidak semua aktivitas perusahaan hanya bermanfaat untuk kepentingan pemilik perusahaan saja, tetapi juga untuk para stakeholder (Puspawati et al, 2018).

\section{Legitimacy Theory}

Gray et al. (1996) berpendapat bahwa : "Teori legitimasi adalah sistem pengelolaan perusahaan yang berorientasi pada keberpihakan terhadap masyarakat, pemerintah individu dan kelompok masyarakat." Maka dari itu aktivitas operasional perusahaan harus sesuai dengan harapan masyarakat. Teori legitimasi yang diterapkan oleh perusahaan yaitu melakukan pengungkapan aktivitas perusahaan di bidang lingkungan dan sosial dalam bentuk laporan keberlanjutan atau dalam bentuk laporan tahunan. Pengungkapan yang telah dilakukan perusahaan merupakan bentuk dari legitimasi aktivitas perusahaan di mata publik, karena merupakan pengungkapan tanggung jawab sosial akan menunjukkan tingkat kepatuhan suatu perusahaan (Branco dan Rodrigues, 2008).

\section{Resource Dependence Theory}

Teori ketergantungan sumberdaya dikemukakan oleh Aldrich dan Pfeffer tahun 1976. Teori ini awalnya dikembangkan untuk memberikan perspektif alternatif bagi para ahli ekonomi mengenai merger dan board interlocks, dan memahami tipe hubungan interorganisasional yang memiliki peranan besar dalam -market failurell belakangan ini. Dasar dari teori ini adalah pernyataan Emerson pada tahun 1962 yang menyatakan bahwa : "Kekuasaan (power) A atas B berasal dari kontrol atas sumberdaya yang dibutuhkan $B$, di mana sumberdaya tersebut tidak ditemukan di tempat lain." Sehingga pengelola perusahaan memiliki motivasi untuk menjamin kelangsungan hidup perusahaan dan meningkatkan otonomi perusahaan yang mereka kelola. Penekanan pada kekuasaan dan penelaahan yang hati- 
hati terhadap taktik yang tersedia bagi pengurus perusahaan merupakan ciciciri dari teori ketergantungan sumberdaya yang membedakannya dengan pendekatan lainnya. Beberapa taktik yang dapat digunakan sebagai contoh adalah jika perusahaan tergantung kepada satu sumber saja untuk keperluan bahan baku, maka cara untuk menjadi lebih otonom adalah dengan mencari dan memelihara sumber alternatif. Taktik lain yang dapat digunakan adalah dengan menjadi besar. Perusahaan besar, memiliki kecenderungan gagal yang lebih kecil dibandingkan perusahaan kecil. Keuntungan lainnya yang diperoleh dari ukuran perusahaan yang besar adalah perusahaan dapat meminta bantuan pemerintah ketika perusahaan tersebut menghadapi masalah (Healy \& Wahlen, 1999).

\section{Pengungkapan Tanggung Jawab Sosial Perusahaan}

Menurut Lanis dan Richardson, 2012 definisi Corporate Social Responsibilty (CSR) secara umum dapat dijelaskan sebagai : "Tanggung jawab perusahaan terhadap lingkungan sekitar untuk meningkatkan kualitas hidup masyarakat sekitar termasuk para pemangku kepentingan (stakeholder)."

Menurut Global Reporting Initiative (GRI) ada beberapa indikator yang diungkapkan ke dalam 91 item pengungkapan dalam mengukur Corporate Social Responsibility (CSR) yaitu:
1. Ekonomi
2. Lingkungan
3. Praktik kerja
4. Hak asasi manusia
5. Kemasyarakatan
6. Tanggung jawab produk

\section{Penghindaran Pajak \\ Menurut Hidayat (2018) : "Penghindaran pajak merupakan upaya pengurangan atau} penghematan pajak sepanjang hal ini dimungkinkan oleh peraturan yang ada." Sedangkan menurut Priantara (2011) dalam Panggabean (2018) : "Tax avoidance merupakan usahausaha yang masih termasuk di dalam konteks peraturan peraturan pajak yang berlaku dengan memanfaatkan celah hukum untuk memperkecil jumlah pajak yang terhutang dari tahun sekarang ke tahun-tahun yang akan datang."

Untuk mengukur tax avoidance di perusahaan digunakan rasio effective tax rate (ETR) dengan rumus: ETR $=\frac{\text { Beban Pajak Penghasilan }}{\text { Pendapatan Sebelum Pajak }}$

\section{Manajemen Laba}

Manajemen laba menurut Rosenzweig dan Fischer, (1994) dalam Sulistyanto (2008) adalah : "Tindakan manajer untuk menaikkan atau menurunkan laba periode berjalan dari sebuah perusahaan yang dikelolanya tanpa menyebabkan kenaikkan (penurunan) keuntungan ekonomi perusahaan jangka panjang."

Untuk mengukur manajemen laba yang dilakukan perusahaan digunakan discretionary accruals dengan rumus sebagai berikut:

DA $_{i, t}=\frac{\text { TAC }_{i, t}}{\text { TA }_{i, t-1}}$

Dimana:

1. $\mathrm{DA}_{\mathrm{i}, \mathrm{t}}$ : Discretionary Accruals perusahaan $i$ pada tahun $t$

2. TAC ${ }_{\mathrm{i}, \mathrm{t}}$ : Total akrual perusahaan $i$ pada tahun $t$ 
3. TA $\mathrm{i}_{\mathrm{i}, \mathrm{t}-1}$ : Total aset perusahaan $i \mathrm{di}$ akhir tahun $t-1$

\section{Koneksi Politik}

Menurut Purwanti dan Sugiyarti (2017) : "Definisi koneksi politik merupakan suatu kondisi di mana terjalin suatu hubungan anatara pihak tertentu dengan pihak yang memiliki kepentingan dalam politik yang digunakan untuk mencapai suatu hal tertentu yang dapat menguntungkan kedua belah pihak." Pronoto dan Widagdo, 2016 menyebutkan bahwasannya : "Perusahaan yang melakukan koneksi politik adalah perusahaan yang mempunyai hubungan istemewa dengan pihak pemerintah." Hubungan istimewa terhadap pihak pemerintah bisa diartikan sebagai perusahaan milik pemerintah, bisa dalam bentuk Badan Usaha Milik Negara (BUMN) dan atau Badan Usaha Milik Daerah (BUMD).

Menurut Anggraeni (2018) untuk mengukur ada tidaknya koneksi politik di perusahaan, digunakan beberapa indikator sebagai berikut :

1. Perusahaan merupakan BUMN atau BUMD yang terdaftar di BEI

Direktur, komisaris, dewan direksi dan komite audit di perusahaan merupakan pejabat pemerintah dalam periode ini maupun periode sebelumnya

\section{METODOLOGI PENELITIAN}

Populasi yang akan digunakan dalam penelitian ini ialah seluruh perusahaan manufaktur yang terdaftar di Bursa Efek Indonesia (BEl) periode 2016-2017. Namun, sampel yang akan digunakan dalam penelitian ini hanya perusahaan manufaktur yang memenuhi beberapa kriteria yang telah ditentukan. Teknik pengambilan sampel yang digunakan dalam penelitian ini adalah purposive sampling. Adapun pertimbangan yang digunakan dalam penelitian ini sebagai berikut :

1. Perusahaan manufaktur yang terdaftar di Bursa Efek Indonesia selama periode 2016-2017.

2. perusahaan yang dijadikan sampel menerbitkan laporannya di Bursa Efek Indonesia selama periode 2016-2017.

3. Perusahaan yang dijadikan sampel tidak mengalami kerugian selama tahun 2016-2017, karena perusahaan yang mengalami kerugian tidak diwajibkan membayar pajak sehingga tidak relevan dengan penelitian ini.

4. Mata uang yang digunakan perusahaan dalam laporan keuangan haruslah Rupiah (Rp).

5. Perusahaan memiliki semua data yang diperlukan untuk variabelvariabel penelitian yang telah ditentukan.

Jenis penelitian dalam penelitian ini merupakan jenis penelitian kuantitatif. Sedangkan jenis data dalam penelitian ini menggunakan jenis data sekunder berupa laporan keuangan dan laporan tahunan dari setiap masing-masing perusahaan manufaktur yang terdaftar di Bursa Efek Indonesia (BEI) periode 20162017, yang mana data laporan keuangan dan laporan tahunan tersebut diperoleh dari website BEI yaitu www.idx.co.id dan website masing-masing perusahaan.

\section{Definisi Operasional Variabel Penelitian}

1. Penghindaran pajak adalah usaha wajib pajak untuk meminimalkan 
beban pajak dengan cara menggunakan alternatif-alternatif yang riil yang dapat diterima oleh fiskus (Aditama, dkk, 2014). Dalam penelitian ini tax avoidance diukur menggunakan rasio effective tax rate (ETR), dengan rumus sebagai berikut:

\section{ETR $=$ Beban Pajak Penghasilan Pendapatan Sebelum Pajak}

2. Manajemen laba ialah Praktek yang muncul ketika manajer mengeluarkan kebijaksanaan manajerial mereka dalam melaporkan pendapatan dengan mengubah informasi keuangan untuk mendistorsi nilai aktual dan menyesatkan pemangku kepentingan pada kinerja ekonomi yang mendasari perusahaan (Healy \& Wahlen, 1999). Dalam penelitian ini manajemen laba diukur menggunakan model discretionary accruals, dengan rumus sebagai berikut:
DA $i, t$

$$
=\frac{\text { TAC }_{i, t}}{T_{i, t-1}}
$$

Dimana:

a. DA i,t : Discretionary Accruals perusahaan $i$ pada tahun $t$

b. TAC i,t : Total akrual perusahaan $i$ pada tahun $t$

c. TA $\mathrm{A}_{\mathrm{i}, \mathrm{t}-1}$ : Total aset perusahaan $i$ di akhir tahun $t-1$

3. Koneksi politik adalah jika pemegang saham otoritas atau petinggi perusahaan adalah anggota parlemen, menteri atau kepala negara, terkait dengan pejabat-pejabat negara, lembaga kenegaraan (Faccio, 2006). Dalam penelitian ini political connection diukur menggunakan beberapa indikator sesuai dengan penelitian Anggraeni (2018).

Adapun indikator dari koneksi politik adalah sebagai berikut:

a. perusahaan merupakan BUMN atau BUMD yang terdaftar di BEI.

b. direktur, komisaris, dewan direksi dan komite audit di perusahaan merupakan pejabat pemerintah dalam periode ini maupun periode sebelumnya.

4. Pengungkapan tanggung jawab sosial perusahaan ialah laporan pengungkapan informasi yang membantu meningkatkan kinerja keuangan, citra dan reputasi perusahaan serta keunggulan dan nilai kompetitif (Amran \& Abdul Khalid, 2009). Dalam penelitian ini CSR diukur menggunakan beberapa indikator sesuai dengan Global Reporting Initiative (GRI). Adapun indikator dari Corporate Social Responsibility (CSR) Disclosure sesuai GRI adalah sebagai berikut:
a. Ekonomi
b. Lingkungan
c. Praktik Kerja
d. Hak Asasi Manusia
e. Kemasyarakatan

Tanggung Jawab Produk

HASIL DAN PEMBAHASAN

\begin{tabular}{|r|r|r|r|l|l|}
\hline \multicolumn{6}{|c|}{ Deskriptive Statistics } \\
\hline & $\mathrm{N}$ & Min & Max & Mean & $\begin{array}{l}\text { Std. } \\
\text { Dev }\end{array}$ \\
\hline TA & 132 & .012 & .922 & .2767 & $\begin{array}{l}.1197 \\
3\end{array}$ \\
31
\end{tabular}




\begin{tabular}{|c|c|c|c|c|c|}
\hline EM & 132 & $\begin{array}{l}- \\
.210\end{array}$ & .847 & $\begin{array}{l}- \\
.0014 \\
9\end{array}$ & $\begin{array}{l}.1001 \\
23\end{array}$ \\
\hline$P C$ & 132 & 0 & 1 & .50 & .502 \\
\hline CSR & 132 & .022 & .824 & $\begin{array}{l}.3964 \\
4\end{array}$ & $\begin{array}{l}.2109 \\
05\end{array}$ \\
\hline $\begin{array}{c}\text { Valid } \\
\mathrm{N}\end{array}$ & 132 & & & & \\
\hline
\end{tabular}

Sumber data : data penelitian diolah kembali (2019)

Berdasarkan hasil data yang telah diolah dengan bantuan SPSS 24, untuk variabel penghindaran pajak skor minimum yang dicapai sebesar 0,012 dan skor maksimum yang dicapai sebesar 0,922 . Untuk variabel manajemen laba skor minimum yang dicapai sebesar $-0,210$ dan skor maksimum yang dicapai sebesar 0,847. Dan untuk variabel tanggung jawab sosial perusahaan skor minimum yang dicapai sebesar 0,022 dan skor maksimum yang dicapai sebesar 0,824 .

\section{Uji Asumsi Klasik}

1. Normalitas

Berdasarkan hasil uji normalitas, tsebaran data berbentuk lonceng, hal ini dapat dikatakan bahwa error regresi berdistribusi normal. Begitupula dengan hasil grafik 4.2, data menyebar disekitar garis diagonal dan mengikuti garis diagonalnya, hal ini menunjukan bahwa model regresi memenuhi asumsi normal.

2. Multikolinearitas

Berdasarkan

uji multikolinearitas, nilai toleransi sebesar 0.979, 0.980, dan 0.999 (mendekati 1) dan nilai VIF sebesar
1.022, 1.020, dan 1.001 (disekitar 1). Hal ini menunjukan bahwa model regresi bebas multikolinearitas.

3. Heterokedastisitas

Berdasarkan heterokedastisitas, uji menyebar secara acak. Maka, dapat dikatakan bahwa model regresi ini tidak terjadi heterokedastisitas (model regresi ini layak dipakai).

\section{Koefisien determinasi $\left(\mathbf{R}^{2}\right)$}

Nilai adjusted $R$ square menunjukan nilai 0,166 atau $16,6 \%$ variabel dependen (pengungkapan tanggung jawab sosial perusahaan) dapat dijelaskan oleh variabel independennya (penghindaran pajak, manajemen laba dan koneksi politik). Sedangkan sisanya yaitu sebesar $83,4 \%$ dijelaskan oleh variabel lain diluar variabel yang diteliti dalam penelitian ini.

\section{Uji t}

Untuk variabel tax avoidance, nilai thitung menunjukan angka sebesar 0,000 dengan tingkat signifikan 1.000 (lebih besar daripada 0,05). Hal ini berarti variabel penghindaran pajak tidak berpengaruh signifikan terhadap variabel pengungkapan tanggung jawab sosial perusahaan. Atau dengan kata lain, pengungkapan CSR perusahaan tidak dipengaruhi oleh tindakan penghindaran pajak yang dilakukan. Atau dengan kata lain, praktik penghindaran pajak yang dilakukan perusahaan belum tentu dapat meningkatkan luasnya pengungkapan tanggung jawab sosial perusahaan. 
Sama halnya dengan variabel manajemen laba, nilai thitung menunjukan angka sebesar $-0,436$ dengan tingkat signifikan 0,664 (lebih besar dari 0,05). Hal ini menunjukan bahwa variabel manajemen laba tidak berpegaruh signifikan terhadap variabel pegungkapan tanggung jawab sosial perusahaan. Atau dengan kata lain, pegungkapan CSR tidak dipengaruhi oleh praktik manajemen laba yang dilakukan perusahaan.

Sedangkan untuk variabel koneksi politik, nilai thitung menunjukan angka sebesar 5,371 (bernilai positif) dengan tingkat signifikan 0,000 (kurang dari 0,05). Hal ini menunjukan bahwa variabel koneksi politik berpegaruh positif dan signifikan terhadap variabel pengungkapan tanggung jawab sosial perusahaan. Perusahaan yang terhubung secara politik akan lebih termotivasi untuk melaksanakan CSR daripada perusahaan yang tidak terhubung dengan pemerintah sejak awal. Sehingga adanya koneksi politik di sebuah perusahaan akan meningkatkan pengungkapan tanggung jawab sosial perusahaan secara lebih luas.

\section{Uji F}

Berdasarkan uji $F$, nilai $F_{\text {hitung sebesar }}$ 9,688 dengan tingkat signifikan 0,000. Hal ini menunjukan bahwa nilai $F_{\text {hitung }}$ lebih besar daripada 4 dan nilai signifikan kurang dari 0,05. Dengan kata lain, semua variabel independen (penghindaran pajak, manajemen laba, dan koneksi politik) mempengaruhi variabel dependen (pengungkapan tanggung jawab sosial perusahaan) secara bersama-sama.

\section{KESIMPULAN}

Hasil penelitian menunjukan bahwa secara parsial, pengindaran pajak dan manajemen laba tidak berpengaruh terhadap pengungkapan tanggung jawab sosial perushaan, dan koneksi politik berpengaruh positif terhadap pengungkapan tanggung jawab sosial perusahaan. Sedangkan secara simultan, penghindaran pajak, manajemen laba, dan koneksi politik berpengaruh secara bersama-sama terhadap pengungkapan tanggung jawab sosial perusahaan.

Nilai adjusted $R$ square menunjukan nilai 0,166 atau $16,6 \%$ variabel dependen (pengungkapan tanggung jawab sosial perusahaan) dapat dijelaskan oleh variabel independennya (penghindaran pajak, manajemen laba, dan koneksi politik). Sedangkan sisanya yaitu sebesar $83,4 \%$ dijelaskan oleh variabel lain diluar variabel yang diteliti dalam penelitian ini.

\section{IMPLIKASI DAN KETERBATASAN}

Berdasarkan pada hasil
penelitian diatas dapat dilihat
bahwasannya variabel dependen
dapat dijelaskan oleh variabel
independennya hanya sebesar 15,9\%
(kurang dari 50\%), sedangkan sisanya
dijelaskan oleh variabel lain yang tidak
diteliti dalam penelitian ini, seperti;
growth, tipe industri dan media
exposure. Sehingga, penulis berharap
untuk peneliti selanjutnya dapat
menambah variabel lain diluar variabel
yang di teliti dalam penelitian ini, agar
variabel dependen dapat dijelaskan
secara menyeluruh.




\section{REFERENCES}

Anggraeni, Rika. 2018. Pengaruh Koneksi Politik Terhadap Tax Aggressiveness

(Studi Empiris : Perusahaan Manufaktur Yang Terdaftar Di Bursa Efek Indonesia Tahun 2014-2017). Universitas Negeri Padang. ARTIKEL yang diterbitkan.

Augustina, Betty, Nurlaela, Siti Dan Hendra, Kartika. 2018. Pengaruh Karakteristik Perusahaan Dan Corporate Social Responsibility Terhadap Tax Avoidance. Jurnal Ekonomi Paradigma. Vol 19, No 02. ISSN: 1693-0827.

Ayufa, Della, NNazar, M Rafki Dan Zultilisna, Djusnimar. 2018. Pengaruh Leverage, Corporate Social Responsibility Dan Ukuran Perusahaan Terhadap Tax Avoidance. Kajian Akuntansi. PP 104-110.

Branco, Manuel Castelo Dan Rodrigues, Lucia Lima. 2008. Factors Influencing Social Responsibility Disclosure By Portuguese Companies. Journal Of Business Ethics. 83:685-701. DOI 10.1007/S10551-007-9658-Z.

Dharmapala, Dhammika and Desai, Mihir A. 2006. Corporate Tax Avoidance and Firm Value. 1st Annual Conference on
Empirical Legal Studies Paper. Available at

SSRN: https://ssrn.com/abstrac $\mathrm{t}=912289$ or http://dx.doi.org/10 $.2139 / \mathrm{ssrn} .912289$.

Dharma, Nyoman Budhi Setya dan Noviari, Naniek. 2017. Pengaruh Corporate Social Responsibility Dan Capital Intensity Terhadap Tax Avoidance. E-Jurnal Akuntansi Universitas Udayana. Vol 18, No 1. ISSN: 2302-8556.

Faccio, Marra. 2006. Politically Connected Firms. The American Economic Review. Vol 96, No 1. pp. 369-386.

Healy, Paul M dan Wahlen James M. 1999. A Review Of The Earnings Management Literature And Its Immplications For Standard Setting. American Accounting Association Journal. Vol 13, Issue 3.

Huang, Haifeng dan Zhao, Zhenrui. 2016. The Influence Of Political Connection On Corporate Social Responsibility Evidence From Listed Private Companies In China. International Journal of Corporate Social Responsibility. Vol 1, No 9. DOI 10.1186/s40991-016-0007-3.

Hutasoit, Rointan Permatasari. 2018. Pengaruh Earning Management Dan Karakteristik Perusahaan Terhadap Pengungkapan Corporate Social Responsibility 
(Studi Empiris pada

Perusahaan Manufaktur yang

Terdaftar Di Bursa Efek Indonesia periode 2014-2016).

Fakultas Ekonomika Dan Bisnis Universitas

Diponegoro

Semarang. SKRIPSI yang diterbitkan.

Jordaan, Lauren A, Klerk, Marna De dan Villiers, Charl J. de. 2018. Corporate Social Responsibility And Earnings Management Of South African Companies. South African Journal of Economic and Management Sciences 21(1), a1849. https://doi. org/10.4102/sajems. v21i1.1849.

Kim, Jeongho dan Im, Chaechang. 2017. Study on Corporate Social Responsibility (CSR): Focus on Tax Avoidance and Financial Ratio Analysis. Sustainability Journal, 9, 1710; doi:10.3390/su9101710.

Lanis, Roman dan Richardson, Grant. 2012. Corporate social responsibility and tax aggressiveness: a test of legitimacy theory. Accounting, Auditing \& Accountability Journal. Vol. 26 No. 1.

Panggabean, Muhammad Rizal. 2018. Pengaruh Corporate Social Responsibility, Ukuran Perusahaan, Struktur Modal Dan Tax Avoidance Terhadap Nilai Perusahaan (Pada Perusahaan Manufaktur Yang
Masuk Dalam Lq45 Di Bursa Efek Indonesia Periode 20112017). Jurnal Kajian Bisnis. Vol. 26, No. 1, Hal $82-94$.

Pratiwi, Indriati Siti dan Djakman, Chaerul Djusman. 2017. The Role of Corporate Political Connections in the Relation of CSR and Tax Avoidance: Evidence from Indonesia. Review of Integrative Business and Economics Research. Vol 6, Supplementary Issue 1.

Pronoto, Bayu Agung dan Widagdo, Ari Kuncoro. 2016. Pengaruh Koneksi Politik Dan Corporate Governance Terhadap Tax Aggressiveness. Syariah Paper Accounting FEB UMS. ISSN 2460-0784.

Purwanti, Shinta Meilina Dan Sugiyarti, Listya. 2017. Pengaruh Intensitas Aset Tetap, Pertumbuhan Penjualan dsan Koneksi Politik Terhadap Tax Avoidance. Jurnal Riset Akuntansi dan Keuangan. Vol 5, No 3.

Puspawati, Dewita, Praswati, Aflit Nuryulia dan Abas, Novel Idris. 2018. Penghindaran Pajak Dan Corporate Social Responsibility: Kinerja Laba Sebagai Variabel Moderasi. University Research Colloquium. STIKES PKU Muhammadiyah Surakarta.

Purwanti, Shinta Meilina Dan Sugiyarti, Listya. 2017. Pengaruh 
Intensitas Aset Tetap, Pertumbuhan Penjualan dsan Koneksi Politik Terhadap Tax Avoidance. Jurnal Riset Akuntansi dan Keuangan. Vol 5, No 3.

Rahman, Intan Maiza Abd dan Ismail, $\mathrm{Ku}$ Nor Izah Ku. 2016. The Effects Of Political Connection On Corporate Social Responsibility Disclosure Evidence From Listed Companies In Malaysia. International Journal of Business and Management Invention. Volume 5, Issue 2.

Santoso, Budi. 2017. Analisis Pengaruh Manajemen Laba, Profitabilitas, Leverage Terhadap Pengungkapan Tanggung Jawab Sosial Perusahaan. Jurnal Universitas Muhammadiyah Jember.

Saraswati, Rara dan Hadiprajitno, Basuki. 2013. Pengaruh Corporate Governance Pada Hubungan Corporate Social Responsibility Dan Nilai Perusahaan Manufaktur Yang Terdaftar Di Bei. Diponegoro Journal Of Accounting. Volume 2, Nomor 1, Halaman 1-11.

Shafai, Nor Atikah Binti, Azlan Bin Amran, dan Ganesan, Yuvaraj. 2018. Earnings Management, Tax Avoidance and Corporate Social Responsibility: Malaysia Evidence. International Academic Journal of Accounting and Financial Management. Vol. 5, No. 3, 2018, pp. 41-56. ISSN 2454-2350.

Sunarsih. 2017. Pengaruh Manajemen Laba Terhadap Corporate Social Responsibility Dengan Mekanisme Corporate Goverance Sebagai Variabel Moderasi. Jurnal Aplikasi IImuIImu Agama. Volume 17, Nomor 1.

Suryadewi, Ida Ayu Intan dan Rasmini $\mathrm{Ni}$ Ketut. 2018. Pengaruh Agresivitas Pajak Pada Corporate Social Responsibility dengan Ukuran Perusahaan Sebagai Pemoderasi. E-Jurnal Akuntansi Universitas Udayana. Vol 23, No 1.

Terzaghi, Muhammad Titan. 2012. Pengaruh Earning Management Dan Mekanisme Corporate Governance Terhadap Pengungkapan Tanggung Jawab Sosial Perusahaan Manufaktur Yang Terdaftar Di Bursa Efek Indonesia. Jurnal Ekonomi dan Informasi Akuntansi. Vol 2, No 1.

Tiarawati, Winda Agustina. 2015. Analisis Pengaruh Pengungkapan Corporate Social Responsibility Terhadap Tax Avoidance (Studi Empiris Pada Perusahaan Manufaktur Yang Terdaftar Di Bei Periode 2009-2013). Jurnal Akuntansi Indonesia, Vol. 4 No. 2 Juli 2015, Hal. $123-142$. 
Wiryadi, Arri dan Sebrina, Nurzi. 2013. Pengaruh Asimetri Informasi, Kualitas Audit, Dan Struktur Kepemilikan Terhadap Manajemen Laba. Wra. Vol 1, No 2.

Wulandari, Soliyah. 2018. The Impact

Of Corporate Social

Responsibility On Accrual
Earnings Management And Real Earning Management. Etikonomi. Vol 15, No 1.

Wardani, Dewi Kusuma dan Purwaningrum, Ratri. 2018. Pengaruh Karakteristik Perusahaan dan Corporate Social Responsibility Terhadap Tax Avoidance. Jurnal Riset Akuntansi. Vol 14, No 1 